\title{
РОЛЬ НАУКОВО-ДОСЛІДНИЦЬКОЇ РОБОТИ СТУДЕНТІВ МЕДИЧНИХ ВНЗ III-IV РІВНІВ АКРЕДИТАЦІЇ В ЇХ СТАНОВЛЕННІ ЯК МАЙБУТНІХ ФАХІВЦІВ
}

\author{
I. В. Геруш, I. М. Яремій, О. Ю. Кушнір \\ Буковинський державний медичний університет, м. Чернівиі
}

\section{ROLE OF SCIENTIFIC AND RESEARCH WORK OF STUDENTS OF MEDICAL HIGHER EDUCATIONAL INSTITUTIONS OF III-IV ACCREDITATION LEVELS IN THEIR DEVELOPMENT AS FUTURE PROFESSIONALS}

\author{
I. V. Herush, I. M. Yaremiy, O. Yu. Kushnir \\ Bukovyna State Medical University, Chernivtsi
}

\begin{abstract}
У роботі викладено роль науково-дослідницької роботи студентів медичних ВНЗ у їх становленні як майбутніх фахівців і формуванні наукової еліти медичної галузі; описано досвід організації роботи студентського наукового гуртка на кафедрі біоорганічної і біологічної хімії та клінічної біохімії Буковинського державного медичного університету.

The paper presents the role of scientific and research work of students of Medical Higher Educational Institutions in their development as future professionals of health care industry and academic elite medical specialization, describes the experience of the organization of students research group at the Department of Bioorganic and Biological Chemistry and Clinical Biochemistry of Bukovyna State Medical University.
\end{abstract}

Вступ. На сучасному етапі розвитку системи вищої медичної освіти в Україні науково-дослідницька робота студентів (НДРС) набуває дедалі більшої актуальності та перетворюється на один із основних компонентів професійної підготовки майбутніх спеціалістів медичної галузі [4]. НДРС вищих медичних навчальних закладів III-IV рівнів акредитації $є$ не лише необхідною умовою успішного навчання за кредитно-модульною системою [1], але й надзвичайно важливим компонентом підготовки майбутніх висококваліфікованих та всебічно розвинених фахівців. Умови сьогодення потребують фахівців, які є не просто високопрофесійними та сумлінними практикуючими лікарями, але й лікарями-дослідниками та, певною мірою, лікарями-експериментаторами, готовими до творчого наукового пошуку, розробки та впровадження в практику охорони здоров'я нових методів діагностики та лікування. НДРС дозволяе певною мірою реалізувати отримані знання, проявити індивідуальність і творчі здібності, готовність до самореалізації особистості [4].

Надзвичайно важливу роль у становленні майбутніх лікарів-науковців відіграє робота обдарованої студент-

( I. В. Геруш, I. М. Яремій, О. Ю. Кушнір ської молоді в студентських наукових гуртках, які плідно працюють при кафедрах медичних ВНЗ ІІІIV рівнів акредитації. Студентський науковий гурток $\epsilon$ важливою формою якісної підготовки майбутніх спеціалістів-медиків [3], адже НДРС готує майбутніх фахівців до творчої роботи, виховує в них вимогливість до себе та точність у роботі, науковість та об'єктивність, розширює світогляд та, насамперед, поглиблює знання з відповідних дисциплін.

Основна частина. Навчання студентів у медичних ВНЗ III-IV рівнів акредитації передбачає два види самостійної НДРС [1-3]: 1) навчальна, передбачена робочими навчальними планами (переважно реферативні повідомлення, наукові доповіді з певної тематики), виконання якої дозволяє студентам отримати додаткові бали до поточної успішності студента 3 певного модуля; 2) індивідуальна самостійна НДР студентів, яка проводиться в позаурочний час у науково-дослідній лабораторії чи клініці під безпосереднім контролем наукового керівника. До виконання останнього виду НДРС залучаються студенти, що глибоко знають навчальну дисципліну і здібні до наукового пошуку та проведення самостійного експериментального дослідження. 
Науково-дослідна робота вимагає від студентів не лише певних знань і вмінь, але й наполегливості та допитливості. Науковий пошук робить навчання студентів творчим і цікавим. Базис пізнавальної діяльності студента закладається викладачами під час лекцій і практичних занять, а сумісна НДР викладача та студента $є$ ключовим моментом освітнього процесу і спрямована на поглиблення теоретичних знань, вдосконалення практичних умінь і навичок 3 відповідної галузі медицини, підготовку ерудованого спеціаліста, який володіє значним об' ємом інформації, здатного кваліфіковано вирішувати професійні завдання на високому науковому рівні, з використанням дослідницьких методів [4].

Однією з основних форм НДРС є пошук наукової літератури з певної тематики, самостійне виконання ними експериментальних досліджень (робота 3 піддослідними тваринами, забір біоматеріалу для дослідження, безпосереднє виконання біохімічних досліджень, виготовлення мікропрепаратів тощо), проведення статистичної обробки фактичного матеріалу, а також аналіз та узагальнення (спільно з науковим керівником) отриманих результатів. Результати досліджень обговорюються на засіданнях студентського наукового гуртка та презентуються студентами на наукових конференціях (усні та стендові доповіді), публікуються в наукових виданнях (статті, тези доповідей).

Такий вид НДРС виконується студентами, які, під керівництвом досвідчених педагогів-науковців, працюють у студентських наукових гуртках. Займаючись у студентських наукових гуртках студенти знайомляться з основами НДР і проводять перші власні наукові дослідження. Це розширює світогляд майбутніх медиків, спонукає їх до самовдосконалення, виробляє у них потяг до наукового пошуку. Під час виконання студентами самостійних наукових досліджень у них помітно зростає інтерес до сучасних клініко-діагностичних методів і відповідальність за роботу, активізується наукове мислення, поглиблюються знання та формується творча активність [4]. До роботи у студентських наукових гуртках залучаються здібні, допитливі, зазвичай добре ерудовані студенти, які хочуть поглибити свої знання, прагнуть до самовдосконалення та бажають бути суспільно корисними.

Участь студента в роботі студентського наукового гуртка дає йому можливість навчитися планувати постановку наукового експерименту, вміння обирати матеріали та методи досліджень, які є адекватними поставленій меті, методи статистичного аналізу отри- маних результатів, забезпечує досконале оволодіння студентами практичних навичок. Проведення аналізу отриманих результатів потребує від студента попереднього ретельного аналізу літературних джерел, які містять новітню інформацію щодо питань, які досліджуються.

Студенти молодших курсів поступово набувають необхідні для проведення самостійного наукового дослідження навички - спершу опановуючи їх на практичних заняттях під час виконання передбачених навчальною програмою лабораторних практикумів, а згодом - займаючись у студентських наукових гуртках.

Студентський науковий гурток допомагає студентам не тільки формувати професійні вміння та вдосконалювати набуті практичні навички, але й розвиває творчий напрямок роботи, клінічне мислення, розширює світогляд [2]. У багатьох студентів саме під час занять у студентських наукових гуртках з'являється серйозний потяг до науки, а набутий під час гурткової роботи досвід стає фундаментом для подальших наукових здобутків. Практично всі науковці розпочинали свій науковий шлях із занять у студентських наукових гуртках, де проводили свої перші наукові дослідження, набували досвіду публічних презентацій своїх наукових доробків і розвивали власні ораторські здібності [2].

До роботи студентського наукового гуртка кафедри біоорганічної і біологічної хімії та клінічної біохімії БДМУ залучаються студенти усіх спеціальностей III-IV рівнів акредитації. Вони проводять експериментальні дослідження з тематик, що безпосередньо пов'язані з їх майбутнім фахом. Так, студенти стоматологічного факультету здійснюють дослідження біохімічних показників ротової рідини, майбутні провізори та клінічні провізори - вплив лікарських засобів на обмін речовин, а студенти спеціальності “Лікувальна справа" - біохімічні зміни показників крові при різних захворюваннях. Надзвичайно продуктивною в науковому сенсі є співпраця студентів різних спеціальностей. Наприклад, студенти медичних факультетів разом із студентами фармацевтичного факультету успішно вивчають біохімічні механізми дії екзогенного мелатоніну та нових синтетичних похідних імідазолів. Активну участь у роботі студентського наукового гуртка кафедри беруть англомовні студенти-іноземці, які приїхали на навчання в БДМУ з Індії, Нігерії, Кенії, Сирії, Йорданії.

Студенти, які займаються в науковому гуртку, регулярно оприлюднюють результати своїх досліджень на засіданнях наукового гуртка, а кращі студенти- 
гуртківці презентують результати своєї наукової діяльності на щорічному міжнародному науковому конгресі студентів і молодих вчених, який проходить у БДМУ $\mathrm{i}$, зазвичай, отримують призові місця. Окрім того, вони беруть активну участь у різноманітних студентських наукових форумах, які проходять в Україні та за ії межами. У 2011 році студенти презентували свої роботи на XV Міжнародному медичному конгресі студентів та молодих вчених у Тернополі, Міжнародній науковій конференції студентів і молодих вчених у Харкові, а також - на VI Міжнародній Пироговській науковій медичній конференції студентів і молодих вчених у Москві (Росія); у 2012 році-на I Всеросійській студентській конференції у Челябінську (Росія) та науково-практичній конференції у Празі (Чехія); у 2013 - на міжнародних наукових конгресах студентів і молодих вчених, які проходили у Києві та Тернополі, науковій конференції у

\section{Література}

1. Бєлаєв Ю. Болонський процес. Хрестоматія/ Ю. Бєлаєв, О. Мішуков. - Херсон : ХДУ, 2005.-276 с.

2. Студентський науковий гурток - як допоміжна форма теоретичного та практичного навчання за кредитномодульною системою / Л. О. Волошина, О. Ю. Оліник, Л. Д. Кушнір [та ін.] // Актуальні питання вищої медичної та фармацевтичної освіти: досвід, проблеми, інновації та сучасні технології : матеріали навчально-методичної конференції. - Чернівці, 2012.-С. 24 .

3. Науково-дослідна робота- одна 3 форм якісної підготовки медичних фахівців / В. А. Гайдуков, І. А. Плеш, Л. Д. Борейко [та ін.] // Актуальні питання вищої медичної
Полтаві, а також виступили з усною доповіддю на 24-й Свропейській студентській конференції у Берліні (Німеччина). Загалом студентами-гуртківцями кафедри біоорганічної і біологічної хімії та клінічної біохімії за 2011-2013 pр. опубліковано 25 наукових праць.

Висновки: 1. Науково-дослідницька робота студентів поглиблює їх знання, розвиває їх вміння логічно мислити та майстерність виконання практичних навичок проведення наукового експерименту, спонукає студентів до самостійного творчого мислення та наукового пошуку, розширює їх світогляд, що загалом підвищує ефективність їх підготовки як майбутніх фахівців.

2. Студентський науковий гурток $є$ найефективнішою формою організації НДРС у медичних ВНЗ IIIIV рівнів акредитації.

та фармацевтичної освіти: досвід, проблеми, інновації та сучасні технології : матеріали навчально-методичної конференції. - Чернівці, 2012. - С. 26.

4. Науково-дослідницька робота студентів як компонент професійної підготовки майбутніх фахівців / О. А. Оленович, Н. В. Пашковська, Л. Б. Павлович, А. А. Ілюшина // Актуальні питання вищої медичної та фармацевтичної освіти: досвід, проблеми, інновації та сучасні технології : матеріали навчально-методичної конференції. - Чернівці, 2012.-C. 56.

Отримано 27.06.14 